\title{
Strategies Sustainable Management of Agroforestry in Climate Change Mitigation and Adaptation
}

\author{
Kamlesh Verma ${ }^{1}$, Prashant Sharma ${ }^{2 *}$, Dhirender Kumar ${ }^{2}$, \\ Satya Prakash Vishwakarma ${ }^{3}$ and Narendar Kumar Meena ${ }^{4}$
}

\author{
${ }^{I}$ Division of Soil and Crop Management, ICAR-Central Soil Salinity Research Institute, \\ Karnal, Haryana, India \\ ${ }^{2}$ Department of Silviculture and Agroforestry, Dr. YSP University of Horticulture and \\ Forestry, Nauni, Solan, Himachal Pradesh, India \\ ${ }^{3}$ Department of Agronomy, ${ }^{4}$ Department of Soil Science and Agricultural Chemistry, Banaras \\ Hindu University, Varanasi, Uttar Pradesh, India
}

*Corresponding author

\section{A B S T R A C T}

\begin{tabular}{l} 
K e y w o r d s \\
Agroforestry, \\
Climate change, \\
Mitigation, \\
Adaptation, \\
sustainable \\
\hline Article Info \\
Accepted: \\
15 December 2020 \\
Available Online: \\
10 January 2021
\end{tabular}

Global climate change caused by rising levels of carbon dioxide $\left(\mathrm{CO}_{2}\right)$ and other greenhouse gases are recognized as a serious environmental issue of the twenty-first century. Climate change leads to land degradation leads to adverse effects on the productivity of the crops thus ultimately affecting the food and livelihood security of the people. Although, agroforestry, the purposeful growing of trees and crops in interacting combinations, has been practised in the world since time immemorial as a traditional land-use system. It is a shining approach which merges century's old knowledge with modern science in a system and the concept of thinking small scale farmer's to achieve potentially big and transformative outcomes. In recent times agroforestry practices are receiving huge attention as a sustainable land-management option because of its ecological, economic, and social attributes. Also, agroforestry simultaneously offers large-scale diversification in agriculture to get supplement fuel, fodder, fruits and fibres on one hand and stabilizing the ecosystems (increase the tree cover, production of timber and other wood products thus reduces the pressure on the forests) on the other hand. Furthermore, agroforestry offers important opportunities to combat climate change by mitigation strategies like carbon sequestration potential and decreasing the greenhouse gases or by adapting to the changing climate like creating the microclimate and increasing the biodiversity. However, in association with this agroforestry also create synergies between both adaptation and mitigation actions which is the necessity of the current times. Especially, agroforestry approaches like the use of Multi-Purpose Tree Species (MPTs), relay-cropping, terracing and contour cultivation, strip and alley cropping are appropriate to fulfil the needs of low-resource farmers by restoring and increasing land productivity through climate change mitigation and adaptation.

\section{Introduction}

In recent years, change in climate has become an important and most complex concern, specifically as a result of scientific warnings about the potential effects of anthropogenic climate forcing on ecological systems, human health, water supplies, agriculture and land- 
use, economic performance, and security (Bailey and Revell, 2015). Currently, the Climate change affecting every country on each continent. The climate change is defined as a change in the state of the climate that can be identified (e.g., by using statistical tests) by changes in the mean and/ or the variability of its properties and that persists for an extended period, typically decades or longer (IPCC, 2019). However, UNFCCC, (1992) elaborated the climate change as a change of climate which is attributed directly or indirectly to human activity that alters the composition of the global atmosphere and which is in addition to natural climate variability observed over comparable periods. In a special report on climate change and land of the Intergovernmental Panel on Climate Change (IPCC 2019) articulate that mean air temperatures have already increased by 1.53 ${ }^{\circ} \mathrm{C}$ from the pre-industrial period (Figure 1). Likewise, changes in the precipitation pattern also recorded (Mishra, 2018).

As food security is the foundation of a stable and healthy nation. However, in the current scenario of climate change (eg. warming, changing precipitation patterns and greater frequency of some extreme events), countries especially the developing one are unable to provide food security (Field et al., 2012; Porter et al., 2014) to the burgeoning population, which will likely reach up to 9.7 billion by 2050 (UN, 2015). Climate change also exacerbates the land degradation by triggering soil erosion, crop failure, loss of biodiversity, reduced soil moisture, pest damages and economic losses, particularly in low lying coastal areas, river deltas, drylands and in permafrost areas (IPCC, 2019) which decreases the agricultural productivity, despite the relativesuccess of intensive agricultural systems that are promotedin many regions of the world (Mbow et al., 2014). However, simultaneously, about 23 per cent of the world's total emission of GHGs viz.,
$\mathrm{CO}_{2}, \mathrm{~N}_{2} \mathrm{O}$ and $\mathrm{CH}_{4}$ come from agriculture, forestry and other land use, like deforestation, livestock production and soil and biodiversity degradation (IPCC, 2019).Moreover, the farmer's ability to continue living on their land depends on how well they adapt to climate change risks.Unfortunately, the effect and consequences of climate change expected to intensify shortly (Haddow and Haddow, 2014). Therefore there is the urgency of the climate change mitigation and adaptation strategies to survive in the tremendously increasing climate change situation.

\section{Mitigation and Adaptation to Climate change}

Mitigation and adaptation are the two major strategies for addressing climate change. Specifically, the mitigation addresses the cause of climate change and is an intervention to reduce the emission sources or enhance the sinks of the GHGs. Although, adaptation addresses the impact of climate change and is an adjustment in the natural or human system in response to actual or expected climatic stimuli or their effects (IPCC, 2001). These two are complementary to each other, as even the strong mitigation efforts, the climate could continue to change in the next decade and thus adaptation. Likewise, adaptation alone will not be able to eliminate all the adverse impacts and mitigation is pivotal to limit climate change (Locatelli 2011). Globally, climate change mitigation focuseson reforestation and forest protection. Although such efforts toreduce tropical deforestation (often under the umbrella ofREDD+) (FAO 2010) conflict with the need to expand agriculturalproduction in Africa to feed the continent's growingpopulation (Mbow et al., 2012). However, agroforestry could be a winwin solutionto the seemingly difficult option between agricultural land use and reforestation, because it increases the storageof carbon and may also enhance 
agricultural productivity (Unruh et al., 1993; Kumar and Nair, 2012). Moreover, Agroforestry systems offer opportunities for the creation of synergies between adaptation and mitigation (Basu 2014).

\section{Agroforestry system}

Agroforestry, a new name to the traditional conspicuous land-use system in which woody perennials are deliberately integrated with the cropsand/or animals on the same piece of a land management unit in some form of spatial arrangement or temporal sequences (Lundgren and Raintree, 1982). Agroforestry systems are currently more common in temperate, sub-tropical and tropical zones, and include a wide range of land uses and practices (Nair, 1985). Agroforestry systems extend over billion ha in diverse eco-region around the world (Kumar and Nair 2011) and havepotential to simultaneously offer diversification in agriculture to get diversified products (fuel, fodder, fruits, fibers) and supplements on the one hand and stabilizing the ecosystems (increase the tree cover thus increasing carbon sequestration potential) on the other hand (Bijalwan, 2013). Thus creates a more integrated, diverse, productive, profitable, healthy and sustainable land-use system than agriculture system (Sharma et al.,2017b).Moreover, directly or indirectly, AGF has potential to significantly contribute toward the most challenging United nation's sustainable development goals (SDGs) like SDG 1 (no poverty), SDG 2 (mitigating hunger, food and nutrition security), SDG3 (healthy live and promote well-being), SDG 5 (women empowerment), SDG 6 (clean water and sanitation), SDG 7 (affordable and clean energy), SDG 13 (climate change mitigation and adaptation), SDG 15 (degraded land restoration and biodiversity loss) (Mbow et al., 2014; Ahmad et al., 2020). Also, agroforestry can restore the ecosystem by the reclamation of the degraded and wastelands
(Sharma et al., 2017a) and the only option to increase the global forest cover. Thus agroforestry has intense potential to generate multiple livelihood and environmental benefits, as it can help to mitigate climate change and help farmers to adapt to extreme and variable weather (Table 1) (IPCC, 2019).

\section{Agroforestry as a climate change mitigation strategy}

Performance of mitigation options in agroforestry will depend on the relative influence of tree species selection and management, soil characteristics, topography, rainfall, agricultural practices, priorities for food security, economic development options, among others (Mbow et al., 2014). Agroforestry mitigation projects can have a positive impact on the local livelihoods and adaptive capacity. They can increase the provision of local ecosystem services to local communities, diversify incomes and economic activities, develop infrastructure or social services, and strengthen local institutions.

\section{Sequester Carbon}

Mainly, the $\mathrm{C}$ sequestration potential of agroforestry systems depends on the plant characteristics (tree species, age, crops, biodiversity, and tree density), system characteristics (structure, function, stability) and management factors (tillage, fertilisation, residues, holding size, and harvesting regime) (Feliciano et al., 2018). Compared to forests, agroforestry plantings have a more open environment resulting in trees with greater branch production and greater specific gravity (Zhou et al., 2011). Although the managed forests and agroforests typically contain less carbon than primary forests, agroforestry systems can, under certain conditions, increase landscape carbon stocks by providing sustainable alternatives to short-fallow slash- 
and-burn agriculture or unshaded tree crops (Matocha et al., 2012). Moreover, Agroforestry systems recognized as having the highest potential for the carbon sequestration by the year 2040 among all the land uses analyzed in the Land-use, Land-use Change and Forestry (LULUCF) report of the IPCC (2000) (Figure 2) and by Murthy et al., (2013).Globally, agroforestry systems can have a wide range of carbon stocks ranging from 29 to $228 \mathrm{Mg} \mathrm{C}^{-1}$ with a median value of $95 \mathrm{Mg} \mathrm{C} \mathrm{ha}^{-1}$ (Albrecht and Kandji 2003).Moreover, agroforestry has a technical mitigation potential of 1.1-2.2 $\mathrm{PgC}$ in terrestrial ecosystems over the next 50 years (Solomon et al., 2007). Moreover, Ramchandran et al., (2010) calculated the carbon stored in the above-ground of agroforestry systems to be in the range of the 0.29-1521 MG ha ${ }^{-1} \mathrm{yr}^{-1}$ whereas 30-300 MG $\mathrm{ha}^{-1} \mathrm{yr}^{-1}$ in $1 \mathrm{~m}$ depth of soil. Additionally, unproductive croplands and grasslands (630 million ha) can be converted to agroforestry representing a carbon sequestration potential of $586,000 \mathrm{MgC} \mathrm{yr}^{-1}$ by 2040 (Jose, 2009).

Furthermore, agroforestry systems have indirect effects on carbon sequestration as they reduce harvesting pressure on natural forests which are the largest sinks for terrestrial carbon (Basu 2014). In the Indian context, the average carbon storage potential estimated to be $25 \mathrm{t} \mathrm{C} \mathrm{ha}^{-1}$ over 96 million ha (Sathaye and Ravindranath, 1998). Moreover, According to Pandey (2002), carbon sequestration in Indian agroforests varies from 19.56 $\mathrm{Mg} \mathrm{C} \mathrm{ha}{ }^{-1} \mathrm{yr}^{-1}$ in north Indian state of Uttar Pradesh to a carbon pool of 23.46-47.36 Mg C ha ${ }^{-1} \mathrm{yr}^{-1}$ in tree-bearing arid agro-ecosystems of Rajasthan. Moreover, as per Annual Report, Jhansi 2018-19, carbon Sequestration potential in agroforestry system existing on farmer's field varied from 0.11 to 0.82tons $\mathrm{C} \mathrm{C} \mathrm{ha}{ }^{-1} \mathrm{yr}^{-1}$ in these states. The maximum CSP of agroforestry system is observed in Maharashtra followed by
AndhraPradesh and Himachal Pradesh (CAFRI 2018, annual report 2018-2019) (Figure 3).

\section{Reduce GHG emissions}

Agroforestry is among the most prominent option to increases the tree cover at the global level. Also, agroforestry systems can meaningfully reduce the pressure on natural forests for energy needs (Mbow et al., 2014). Thus, simultaneously reduces the dependency on fossil fuel. Moreover, the increased soil organic carbon increases nutrient cycling,vigorous soil fauna, optimal soil structure, and improved soil water regimes (Doran et al., 1994). Also, the establishment of the legume-based alley cropping has both direct and indirect benefits. Directly, it reduces the demand for the $\mathrm{N}$ fertilizers and indirectly decreases the input cost. The decrease in the fertilizer demand beneficial for the environment as sometimes peat used as organic fertilizer thus degrade peatland which contains twice carbon than standing forest lands (IUCN 2017). Furthermore, trees in agroforestry produce the safety net which has potential to take up excess $\mathrm{N}$ in time and space in association with the potential of the tree to uptake excess $\mathrm{N}$ (Bergeron et al., 2011). Also, silvopasture agroforestry system has potential to several ways to reduce the $\mathrm{CH}_{4}$ and $\mathrm{N}_{2} \mathrm{O}$ emissions (Mutuo et al., 2004; Allen et al., 2009; Eckard et al., 2010; BaahAcheamfour et al., 2017). AFS are estimated to offset one-third (33\%) of the total GHG emissions from agriculture sector annually at country-level in association with the mitigation more than $6 \%$ of total GHG emissions (Ajit et al., 2017). Moreover, the shading in agroforestry systems affects the morphology, anatomy and chemical composition of intercropped forages and therefore affects forage quality (Lin et al., 2001). Thus shading in agroforestry systems supposed to increase the forage quality and 
further decreases the $\mathrm{CH}_{4}$ emissions from the livestock.

\section{Agroforestry as a climate change adaptation strategy}

Agroforestry for climate adaptation at the farm level and enhanced resilience at the landscape level can take many forms. There are various ways through which agroforestry increases the farmer's resilience in the era of climate change by adapting to this situation.

\section{Microclimate moderation}

Agroforestry has the potential to alter the microclimate of the area by lowering the temperature, evapotranspiration, moisture reduction, acting as a filter and providing a buffer against direct sunlight (Chavan et al., 2014) (Figure 4). Moreover, agroforestry can reduce air pollution and enhance both warming and cooling of the atmosphere, creating a resilient microclimate for crops and livestock (Ellison et al., 2017). Simultaneously, enhances water security through improved infiltration to soils and groundwater, protecting water catchments and watersheds.

Moreover, trees provide several ecosystem services, such as water regulation, climate buffering, soil fertility, erosion and flood control, as well as food, fodder, medicine and wood - all-important for resilience to climate change and reduced vulnerability of local people (Verchot et al., 2007; Mbow et al., 2014). Lott et al., (2003) stated that about $25 \%$ of the water transpired by trees is used during the dry season, indicating that they can utilize offseason rainfall (comprising 15-20\% of the total annual rainfall) and residual soil water after the cropping period, with the rest being lost by evaporation (40\%) or deep drainage $(33-40 \%)$. During periods of excessive soil moisture, tree-based systems can maintain aerated soil conditions by pumping out excess water. Furthermore, Microclimatic improvement through agroforestry has a major impact on crop performance as trees can buffer climatic extremes that affect crop growth (Mbow et al., 2014).

Furthermore, plant stress, as well as shifts in woody plant disease, pest and natural enemy dynamics created by weather extremes, and the longer-term predicted shifts in climate, will play a dominant role in the persistence and performance of all agroforestry plants, herbaceous or woody.

\section{Biodiversity conservation}

Agroforestry systems comprise a long list of land management practices, including crop diversification, long rotation systems for soil conservation, home gardens, boundary plantings, perennial crops, hedgerow intercropping, live fences, improved fallows or mixed strata agroforestry (Mbow et al., 2014).

The potential to improve soil properties and water availability to plants also make agroforestry practices suitable for landscape restoration. Agroforestry provides shelter for soil flora \& fauna, birds, insects and wildlife. Jose (2012) argued that agroforestry system helps in conserving and enhancing the biodiversity.

Agroforestry, in general, may increase farm profitability through improvement and diversification of output per unit area of tree/crop/livestock, through protection against damaging effects of wind or water flow, and new products added to the financial diversity and flexibility of the farming enterprise. 
Table.1 Agroforestry potential to address climate change mitigation and adaptation.

(Schoeneberger et al., 2012)

\begin{tabular}{|c|c|c|c|}
\hline & Major CC function & Agroforestry functions \\
\hline \multirow{5}{*}{ 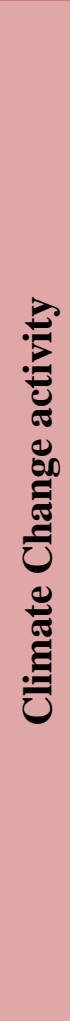 } & \multirow[b]{2}{*}{ } & Sequester C & $\begin{array}{l}\text { Accumulate } \mathrm{C} \text { in woody biomass } \\
\text { in Soil }\end{array}$ \\
\hline & & $\begin{array}{l}\text { Reduce GHG } \\
\text { emissions }\end{array}$ & $\begin{array}{l}\text { Reduce fossil fuel consumption } \\
\text { Reduce equipment runs in areas with trees } \\
\text { Reduce farmstead heating and cooling } \\
\text { Reduce } \mathrm{CO}_{2} \text { emission from farmstead structures } \\
\text { Reduce } \mathrm{NO}_{2} \text { emission } \\
\text { Greater nutrient uptake through plant diversity } \\
\text { Reduced } \mathrm{N} \text { fertilizer application in tree component } \\
\text { Enhance forage quality, thereby reducing } \mathrm{CH}_{4}\end{array}$ \\
\hline & & & \\
\hline & \multirow{2}{*}{$\frac{\stackrel{\Xi}{0}}{\stackrel{0}{\frac{\pi}{\pi}}}$} & $\begin{array}{l}\text { Reduce threats \& } \\
\text { enhance resilience }\end{array}$ & $\begin{array}{l}\text { Alter microclimate to } \\
\text { reduce extreme weather impact on crop } \\
\text { maintain quality and quantity of forage production } \\
\text { reduce livestock stress } \\
\text { Greater structural and functional diversity } \\
\text { Diversified product to reduce fluctuating climate risk }\end{array}$ \\
\hline & & $\begin{array}{l}\text { Allow species to } \\
\text { migrate to more } \\
\text { favourable } \\
\text { conditions }\end{array}$ & Travel corridors for species migration \\
\hline
\end{tabular}

Fig.1 Climate Change to Date. Source: From NOAA State of the Climate. https://www.ncdc.noaa.gov/cag/global/time-series/globe/land/ytd/12/1910-2020

Global Land

January-December Temperature Anomalies

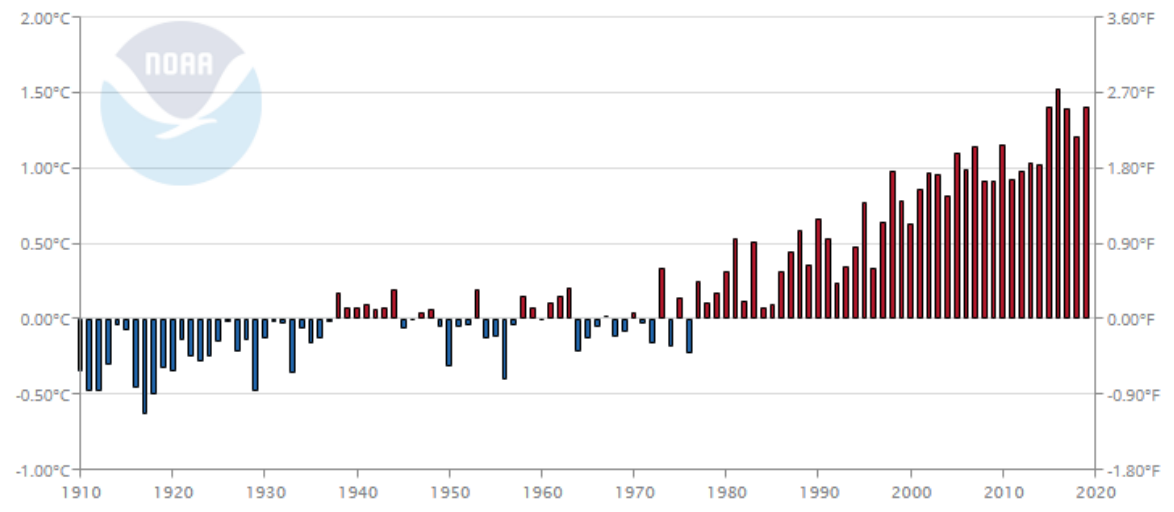


Fig.2 Carbon sequestration potential of different land use management systems (IPCC, 2000)

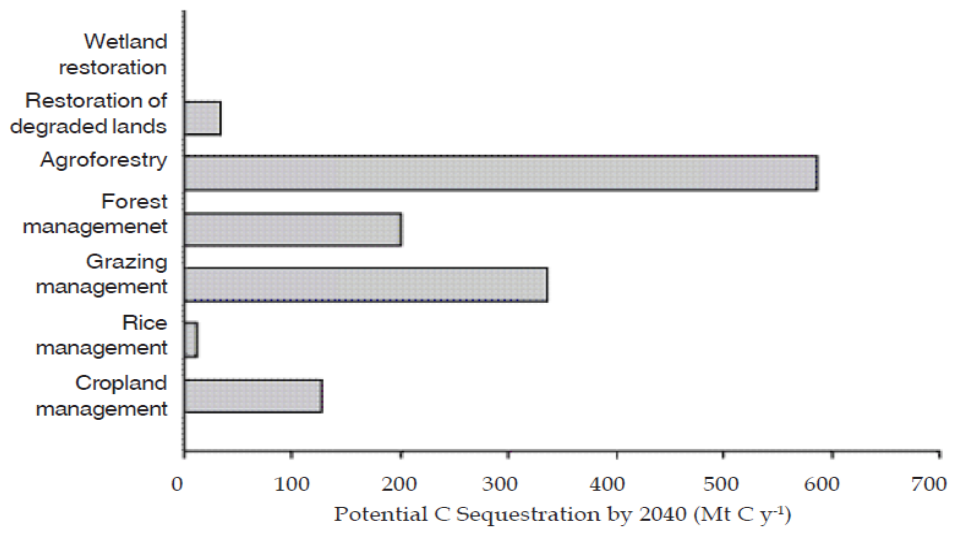

Fig.3 Carbon Sequestration potential in agroforestry system existing on farmer's field in India (CAFRI 2018, annual report 2018-2019)

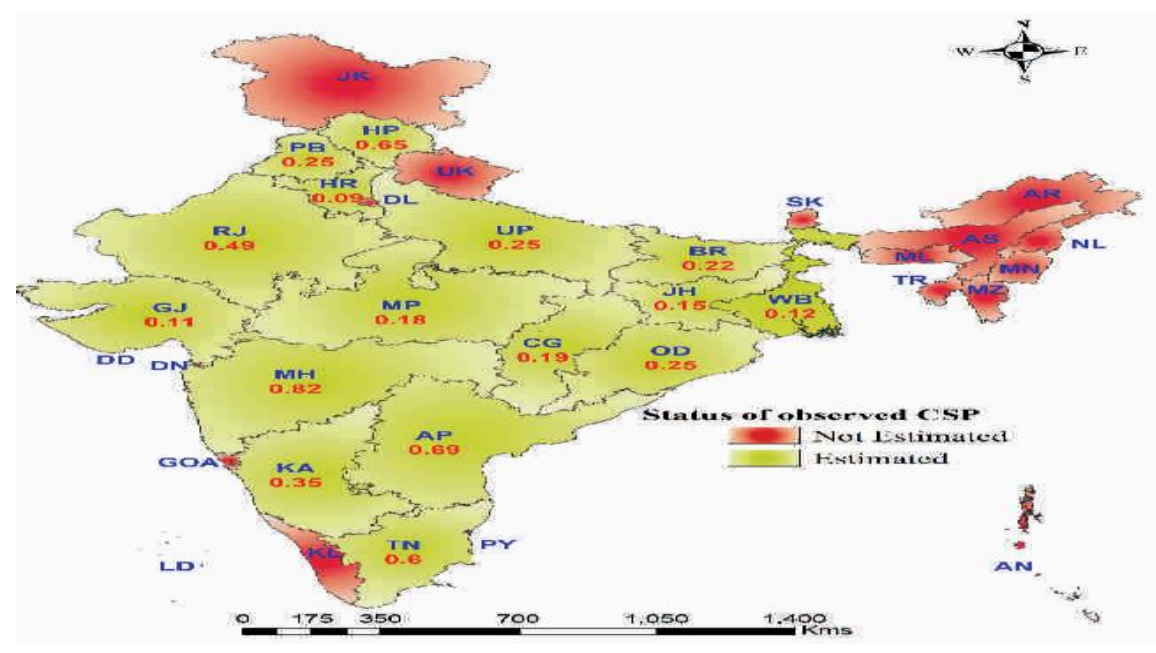

Fig.4 Processes through which tree improve the soils

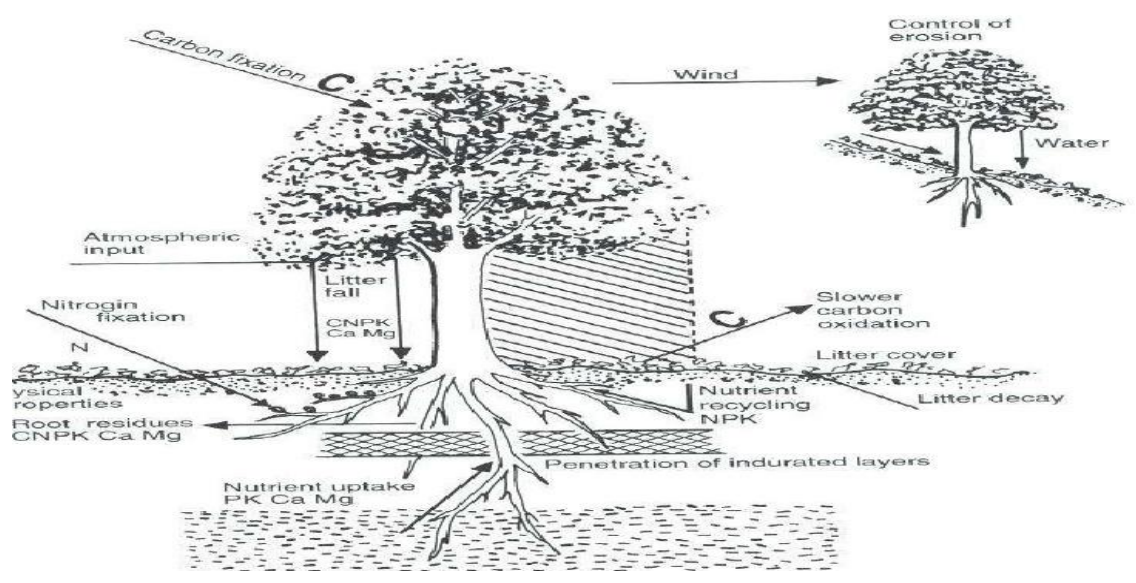




\section{Reclamation of degraded land}

Land degradation is one of the foremost issues in India that leads to deterioration of land quality for agricultural production and environmental protection. In India, about 147.75 $\mathrm{M}$ ha land comes under the degraded land occur through different physical, chemical and biological processes induced directly or indirectly by human activities like deforestation, shifting cultivation, overgrazing, steep slope farming, overuse of chemical fertilizers and forest resources. Agroforestry has potential to prevent land degradation while allowing continuing use of land by checking soil erosion to some extent, increase soil fertility, reduce salinity; alkalinity, acidity, and desertification etc. ultimately improve soil health which keeps the land suitable for the sustainable production of diversified products. Agroforestry approaches like the use of multipurpose tree species (MPTs), relay-cropping, terracing and contour cultivation, strip and alley cropping are appropriate to fulfil the needs of low-resource farmers by restoring and increasing land productivity. By utilizing the degraded lands, the burden on the forest can be decreased thus primary forest can be used for their real benefits (Sharma et al., 2017a).

In conclusion, agroforestry is one of several climate change mitigation and adaptation tools that will be needed for agricultural lands under the uncertainty of climate change. Agroforestry systems readily bundle both mitigation and adaptation strategies and provide several pathways to securing food security for poor farmers, while contributing to climate change mitigation. Most of these benefits have direct benefits for local adaptation while contributing to global efforts to control atmospheric greenhouse gas concentrations. There is a need to build a bridge between adaptation and mitigation measures for creating environmental secure options of carbon sequestration with multifunctional benefits from agroforestry. Agroforestry should attract more attention in global agendas on mitigation because of its positive social and environmental impacts. However, uncertainties related to future climates, land use and land cover, soil fertility in drier environments and pests and diseases pose challenges to the scaling up of agroforestry practices. Furthermore, small and fragmented sizes of the agroforestry patches severely hamper their participation in carbon projects.

\section{References}

Ahmad, F., Uddin, M. M., Goparaju, L., Rizvi, J., \& Biradar, C. (2020). Quantification of the Land Potential for Scaling Agroforestry in South Asia. KN-Journal of Cartography and Geographic Information, 70(2), 1-19.

Ajit, Dhyani, S. K., Handa, A. K., Newaj, R., Chavan, S. B., Alam, B., Prasad, R., ... \& Shakhela, R. R. (2017). Estimating carbon sequestration potential of existing agroforestry systems in India. Agroforestry Systems, 91(6), 1101-1118.

Albrecht, A., \& Kandji, S. T. (2003). Carbon sequestration in tropical agroforestry systems. Agriculture, Ecosystems \& Environment, 99(1-3), 15-27.

Allen, D. E., Mendham, D. S., Cowie, A., Wang, W., Dalal, R. C., \& Raison, R. J. (2009). Nitrous oxide and methane emissions from soil are reduced following afforestation of pasture lands in three contrasting climatic zones. Soil Research, 47(5), 443-458.

Baah-Acheamfour, M., Chang, S. X., Bork, E. W., \& Carlyle, C. N. (2017). The potential of agroforestry to reduce atmospheric greenhouse gases in Canada: Insight from pairwise 
comparisons with traditional agriculture, data gaps and future research. The Forestry Chronicle, 93(2), 180-189.

Bailey I and Revell P (2015). Climate change. In: Smelser, N. J., \& Baltes, P. B. (Eds.). International encyclopedia of the social \& behavioral sciences (Vol. 11). Amsterdam: Elsevier.

Basu, J. P. (2014). Agroforestry, climate change mitigation and livelihood security in India. In New Zealand Journal of Forestry Science (Vol. 44, No. S1, p. S11). Springer International Publishing.

Bergeron, M., Lacombe, S., Bradley, R. L., Whalen, J., Cogliastro, A., Jutras, M. F., \& Arp, P. (2011). Reduced soil nutrient leaching following the establishment of tree-based intercropping systems in eastern Canada. Agroforestry Systems, 83(3), 321-330..

Chavan, S., Newaj, R., Keerthika, A., Ram, A., Jha, A., \& Kumar, A. (2014). Agroforestry for adaptation and mitigation of climate change. Popular Kheti, 2(3).

Doran, J. W., \& Parkin, T. B. (1994). Defining and assessing soil quality. Defining Soil Quality for a Sustainable Environment, 35, 1-21.

Eckard, R. J., Grainger, C., \& De Klein, C. A. M. (2010). Options for the abatement of methane and nitrous oxide from ruminant production: a review. Livestock Science, 130(1-3), 47-56.

Ellison, D., N. Futter, M., \& Bishop, K. (2012). On the forest cover-water yield debate: from demand-to supply-side thinking. Global

Change

Biology, 18(3), 806-820.

FAO. (2010). Global Forest Resources Assessment 2010. Rome:FAO.

Feliciano, D., Ledo, A., Hillier, J., \& Nayak,
D. R. (2018). Which agroforestry options give the greatest soil and above ground carbon benefits in different world regions?. Agriculture, Ecosystems \& Environment, 254, 117129.

Field, C., Barros, V. et al. (Eds.), (2012). Managing the Risks of Extreme Events and Disasters to Advance Climate Change Adaptation. A Special Report of Working Groups I and II of the Intergovernmental Panel on Climate Change, Cambridge University Press, Cambridge, UK, and New York, USA.

Haddow, G. D., \& Haddow, K. S. (2013). Disaster communications in a changing media world. ButterworthHeinemann.

IPCC (2000) Land use, land-use change, and forestry. Cambridge University Press, Cambridge, UK, p 375 A special report of the IPCC

IPCC, (2019). IPCC Special Report on Climate Change, Desertifcation, Land Degradation, Sustainable Land Management, Food Security, and Greenhouse gas fluxes in Terrestrial Ecosystems. Intergovernmental Panel on Climate Change.

IPCC, T. (2001). Watson, RT; and the Core Writing Team, ed., Climate Change 2001: Synthesis Report, Contribution of Working Groups I, II, and III to the Third Assessment Report of the Intergovernmental Panel on Climate Change.

IUCN (2017) Peatlands and Climate change. https://www.iucn.org/resources/issuesbriefs/peatlands-and-climate-change

Jose, S. (2009). Agroforestry for ecosystem services and environmental benefits: an overview. Agroforestry systems, 76(1), $1-10$.

Kumar, B. M., \& Nair, P. R. (Eds.). (2011). Carbon sequestration potential of agroforestry systems: opportunities 
and challenges (Vol. 8). Springer Science \& Business Media.

Lin, C. H., McGraw, M. L., George, M. F., \& Garrett, H. E. (2001). Nutritive quality and morphological development under partial shade of some forage species with agroforestry potential. Agroforestry Systems, 53(3), 269-281.

Locatelli B. (2011). Synergies between adaptation and mitigation in a nutshell. https://www.cifor.org/fileadmin/fileupl oad/cobam/ENGLISHDefinitions\%26ConceptualFramework. pdf

Lott, J. E., Khan, A. A. H., Black, C. R., \& Ong, C. K. (2003). Water use in a Grevillea robusta-maize overstorey agroforestry system in semi-arid Kenya. Forest ecology and management, 180(1-3), 45-59.

Matocha, J., Schroth, G., Hills, T., \& Hole, D. (2012). Integrating climate change adaptation and mitigation through agroforestry and ecosystem conservation. In Agroforestry-the future of global land use (pp. 105-126). Springer, Dordrecht.

Mbow, C., Skole, D., Dieng, M., Justice, C., Kwesha, D., Mane, L., ... \& Virji, H. (2012). Challenges and prospects for REDD+ in Africa: desk review of REDD+ implementation in Africa. Global Land Project Reports, 5. Mbow, C., Smith, P., Skole, D., Duguma, L., \& Bustamante, M. (2014). Achieving mitigation and adaptation to climate change through sustainable agroforestry practices in Africa. Current Opinion in Environmental Sustainability, 6, 8-14.

Mishra, A. K. (2019). Quantifying the impact of global warming on precipitation patterns in India. Meteorological Applications, 26(1), 153-160.

Murthy, I. K., Gupta, M., Tomar, S., Munsi, M., Tiwari, R., Hegde, G. T., \& Ravindranath, N. H. (2013). Carbon sequestration potential of agroforestry systems in India. J Earth Sci Climate Change, 4(1), 1-7.

Mutuo, P. K., Cadisch, G., Albrecht, A., Palm, C. A., \& Verchot, L. (2005). Potential of agroforestry for carbon sequestration and mitigation of greenhouse gas emissions from soils in the tropics. Nutrient cycling in Agroecosystems, 71(1), 43-54.

Nair P.K.R. (1985). Classification of agroforestry systems, Agroforestry System 3 97-128.

Nair, P. R., Nair, V. D., Kumar, B. M., \& Showalter, J. M. (2010). Carbon sequestration in agroforestry systems. In Advances in agronomy (Vol. 108, pp. 237-307). Academic Press.

Pandey, D. N. (2002). Carbon sequestration in agroforestry systems. Climate policy, 2(4), 367-377.

Porter, J.R., Xie, L., et al. (2014). Climate change 2014: impacts, adaptation, and vulnerability. Working Group II contribution to the IPCC Fifth Assessment Report. IPCC, authors include: Coordinating lead authors, lead authors, contributing authors and review editors.

Sathaye, J. A., \& Ravindranath, N. H. (1998). Climate change mitigation in the energy and forestry sectors of developing countries. Annual Review of Energy and the Environment, 23(1), 387-437.

Schoeneberger, M., Bentrup, G., De Gooijer, H., Soolanayakanahally, R., Sauer, T., Brandle, J., ... \& Current, D. (2012). Branching out: Agroforestry as a climate change mitigation and adaptation tool for agriculture. Journal of Soil and Water Conservation, 67(5), 128A-136A.

Sharma, P., Singh, M. K., \& Tiwari, P. (2017a). Agroforestry: A Land Degradation Control and Mitigation 
Approach. Bulletin of Environment, Pharmacology and Life sciences, 6(5), 312-317.

Sharma, P., Singh, M. K., Tiwari, P., \& Verma, K. (2017b). Agroforestry systems: Opportunities and challenges in India. Journal of Pharmacognosy and Phytochemistry, SP1, 953-957.

Solomon, S., Manning, M., Marquis, M., \& Qin, D. (2007). Climate change 2007the physical science basis: Working group I contribution to the fourth assessment report of the IPCC (Vol. 4). Cambridge university press.

UNFCCC, $1992 . \quad$ Article 1.,http://unfccc.int/resource/docs/convk p/conveng.pdf.

Unruh, J. D., Houghton, R. A., \& Lefebvre, P. A. (1993). Carbon storage in agroforestry: an estimate for subSaharan Africa. Climate Research, 3(12), 39-52.
Verchot LV, Noordwijk MV, Kandji S, Tomich T, Ong C, Albrecht A, Mackensen J, Bantilan C, Anupama KV, Palm C, (2007). Climate change: linking adaptation and mitigation through agroforestry. Mitigation Adapt Strat Global Change 12:901-918.

Watson, R. T., Noble, I. R., Bolin, B., Ravindranath, N. H., Verardo, D. J., \& Dokken, D. J. (2000). IPCC special report on land use, land-use change, and forestry.

Zhou, X., Brandle, J. R., Awada, T. N., Schoeneberger, M. M., Martin, D. L., Xin, Y., \& Tang, Z. (2011). The use of forest-derived specific gravity for the conversion of volume to biomass for open-grown trees on agricultural land.biomass and bioenergy,35(5), 1721-1731.

\section{How to cite this article:}

Kamlesh Verma, Prashant Sharma, Dhirender Kumar, Satya Prakash Vishwakarma and Narendar Kumar Meena. 2021. Strategies Sustainable Management of Agroforestry in Climate Change Mitigation and Adaptation. Int.J.Curr.Microbiol.App.Sci. 10(01): 2439-2449. doi: https://doi.org/10.20546/ijcmas.2021.1001.282 